\title{
Kekerasan dalam Pacaran: Anatomi Konflik dan Penyelesaiannya
}

\author{
Wahyu Budi Nugroho, ${ }^{1 *}$ Sukma Sushanti ${ }^{2}$ \\ 1,2Universitas Udayana, Bali - Indonesia
}

\begin{abstract}
This article aims to study one of the social relationship forms called "love relationship". Love relationships may define as a relation between two individuals, opposite sex generally, in addition, to adapt to each other before marriage. As one of the social relationship forms, it can not avoid conflict, even violence. Those concerns are becoming the focus study in this research. Furthermore, this research using the individual's conflict theory by George Simmel, conflict theory of Lewis A. Coser, and also existential sociology of Jean-Paul Sartre about love. The method of this research is qualitative which explanative-descriptive research variant. Based on the research, it is found that most of the informants lie love relationship in "functional" form. Despite this, most of them are not realized of love relationship violence which held. Finally, the resolution of all matters took moderate to radical form, it is reconciliation or broke up, and even not engaged anymore.

Artikel ini berupaya mengkaji salah satu wujud relasi sosial antarindividu yang sering diistilahkan dengan "pacaran". Secara sederhana, pacaran adalah relasi intim antara dua individu yang umumnya berlawanan jenis, yang bertujuan sebagai tahap awal penjajakan sebelum keduanya memutuskan ke jenjang yang lebih serius, yakni pernikahan. Sebagai salah satu bentuk relasi sosial, tentunya pacaran tidak terlepas dari konflik, bahkan kekerasan, fenomena inilah yang akan dikaji lebih jauh dalam penelitian ini. Terkait hal tersebut, penelitian ini menggunakan teori konflik antarindividu dari George Simmel, teori konflik Lewis A. Coser, serta sosiologi eksistensialisme Jean Paul Sartre mengenai cinta. Adapun metode penelitian yang digunakan adalah kualitatif dengan jenis penelitian deksriptif-eksplanatif. Melalui penelitian yang telah dilakukan, ditemukan bahwa sebagian besar informan cenderung menempatkan hubungan pacaran secara "fungsional". Di samping itu, seringkali para informan juga tidak menyadari jika telah menuai bentuk-bentuk kekerasan dalam pacaran. Adapun penyelesaian dari persoalan tersebut mengambil wujud moderat hingga radikal, yakni dari rekonsiliasi hingga putus dengan pasangan, dan sama sekali tidak berhubungan lagi.
\end{abstract}

Keywords: love relationships; conflict anatomy; violence; resolution

*Korespondensi Penulis: Wahyu Budi Nugroho (wahyubudinug@unud.ac.id). Kampus Bukit, Jl. Raya Kampus Universitas Udayana, Jimbaran, Kec. Kuta Selatan, Kabupaten Badung, Bali, Indonesia 80361. 


\section{Pendahuluan}

Secara sosiologis, pacaran adalah bentuk relasi sosial antarindividu yang memiripkan wujudnya dengan hubungan persahabatan, hubungan antara orangtua dengan anak, hubungan antara suami dengan istri, dan hubungan-hubungan sosial lainnya sejauh ia sekadar melibatkan dua orang (Sharma, 2015). Sebagai salah satu wujud relasi sosial, tentunya hubungan pacaran tidak terlepas dari konflik. Konflik sebagaimana dimaksudkan di sini mengambil bentuknya dari moderat hingga ekstrem; dari persaingan, pertentangan, perselisihan, kontravensi, diskonformitas, hingga kekerasan (Wieviorka 2013). Meskipun memang secara sosiologis, konflik dapat dibedakan dari kekerasan; sebagaimana penjelasan Tabel 1 .

Namun demikian, dapatlah dikatakan, setiap kekerasan selalu menemui wujudnya sebagai konflik, dan setiap konflik belum tentu berekses pada kekerasan. Sebagaimana telah disinggung sebelumnya, pacaran sebagai salah satu wujud relasi sosial, tentunya tidak terlepas dari konflik. Dalam batas-batas tertentu, konflik dalam proses interaksi antarindividu menjadi sesuatu yang wajar, akan tetapi hal ini menjadi tidak wajar apabila konflik menyinggung "tema inti", berikut memunculkan kekerasan (Poloma, 1979). Dalam ranah sosial, pacaran telah menjadi fenomena mafhum (biasa), bahkan kini tidak hanya dilakukan oleh orang dewasa dan remaja, tetapi juga anak-anak. Tidak dapat dipungkiri, terdapat berbagai motivasi individu dalam menjalin relasi pacaran. Bagi individu dewasa, pacaran yang dilakukan biasanya bersifat serius, sebagai upaya yang dilakukan untuk menemukan pendamping hidup hingga akhir hayat. Bagi remaja dan anakanak, biasanya hubungan pacaran dilandasi oleh motivasi "senang-senang", yakni ketika mereka memiliki ketertarikan seksual, atau kematangan seksual.

Di lain sisi, pandangan masyarakat pun seolah terpecah dalam hal ini, ada beberapa elemen masyarakat yang bersifat asertif (membolehkan) terhadap pacaran, namun ada juga yang merekomendasikan untuk tidak melakukan pacaran, hingga yang terkonservatif: melarangnya sama sekali. Mereka yang membolehkan pacaran umumnya berasal dari keluarga cukup terdidik, dengan pandangan agamis liberal atau moderat,

Tabel 1.

Perbedaan antara konflik dengan kekerasan (tabel diolah penulis)

\begin{tabular}{lll}
\hline & \multicolumn{1}{c}{ Konflik } & \multicolumn{1}{c}{ Kekerasan } \\
\hline ...berdasarkan sifatnya & $\begin{array}{l}\text { Proses interaksi sosial yang } \\
\text { bersifat negatif dan disosiatif. }\end{array}$ & $\begin{array}{l}\text { Agresi jahat yang tidak } \\
\text { terprogram. }\end{array}$ \\
\hline ...sebagai fenomena & $\begin{array}{l}\text { Hal yang umum di masyarakat } \\
\text { dan dalam hubungan } \\
\text { antarindividu; fakta sosial yang } \\
\text { tidak bisa dihindari. }\end{array}$ & $\begin{array}{l}\text { Tidak umum, bukan hal yang } \\
\text { wajar, dan memiliki tingkat } \\
\text { destruktif yang berbeda-beda. }\end{array}$ \\
\hline Dapat berdampak positif. & $\begin{array}{l}\text { Sama sekali tidak berdampak } \\
\text { positif; skala kekerasan dapat } \\
\text { meningkat dari waktu ke waktu. }\end{array}$ \\
\hline
\end{tabular}


sedangkan mereka yang bersifat mendua (raguragu) mengenai ini, biasanya berasal dari keluarga dengan basis agama moderat. Sementara, mereka yang sama sekali menolak pacaran umumnya berasal dari keluarga dengan kehidupan agama yang sangat konservatif, bahkan bisa juga dikatakan "garis keras" (Selarani, 2018).

Lebih jauh, hal menarik yang terdapat dalam relasi pacaran adalah proses sosial yang terdapat di dalamnya. Pertama, ketika antarindividu bertemu dan tertarik satu sama lain. Di sini, dimensi "simpati" berperan penting di dalamnya. Tidak hanya itu saja, strategi komunikasi (interaksi) yang dilancarkan antara satu terhadap pihak lain agaknya juga menarik untuk dikaji di mana "dramaturgi" tentu turut berperan. Di samping itu, apabila individu mengenal "calon pasangan" lewat perantara individu lain, maka "modal sosial" turut bekerja pada proses ini. Kedua, motivasi individu untuk menjalin relasi pacaran. Motivasi individual ini dapat ditilik lebih jauh melalui konsep rasionalitas yang terdiri dari; rasionalitas formal, instrumental, nilai, ataukah afektif. Ketiga, konsensus atau persetujuan ketika dua individu berlawanan jenis ini mengikat janji dalam relasi pacaran. Keempat, yakni setelah dua individu mengikat janji dalam relasi pacaran, dalam hal ini, proses interaksi sebelum individu berpacaran dan sesudahnya dapat ditinjau kembali: apakah terdapat perbedaan ataukah tidak; dan jika ada, rasionalisasi semacam apa yang menyebabkan perubahan pola-pola interaksi itu.

Pada akhirnya, hal yang tidak dapat terhindarkan dalam relasi pacaran adalah konflik yang terjadi di dalamnya. Konflik dalam relasi ini sesungguhnya patut ditempatkan sebagai hal yang serius mengingat telah banyak terjadi konflikkonflik dalam hubungan pacaran yang berekses pada kekerasan, bahkan hingga hilangnya nyawa individu. Sayangnya, hal-hal demikian seringkali telah terjadi terlebih dahulu sebelum tindakan preventif dilakukan. Serangkaian paparan di atas kiranya menarik untuk dikaji lebih jauh, yakni berkenaan dengan proses-proses sosial yang berlangsung dalam tahapan-tahapan semenjak individu bersimpati terhadap individu lain hingga memutuskan untuk menjalin relasi pacaran, serta pola-pola interaksi yang terjalin dalam berlangsungnya proses pacaran itu sendiri. Terakhir, hal yang juga mengusik untuk dikaji adalah bagaimana konflik, bahkan kekerasan baik fisik maupun verbal justru terjadi dalam relasi dua individu yang saling menyayangi berikut mencintai.

Terdapat beberapa tulisan sebelumnya yang mengkaji tentang relasi pacaran. Pertama, Dampak Pacaran terhadap Moralitas Remaja menurut Ustadz Jefri al-Bukhari oleh Romaeti (2011). Kedua, Perspektif Pendidikan Islam mengenai Pacaran oleh Rahayu (2015). Ketiga, Gambaran Konsep Pacaran dan Perilaku Pacaran pada Remaja Awal oleh Pratiwi (2012). Keempat, Hubungan antara Ekspresi Cinta dengan Perilaku Pacaran Remaja Madrasah Tsanawiyah oleh Muslimah (2013). Kelima, Perilaku Berpacaran pada Remaja di Desa Batubelah, Kecamatan Kampar, Kabupaten Kampar oleh Indrayani (2016). Artikel ini sama-sama menjadikan fenomena pacaran sebagai objek kajian.

Adapun perbedaannya antara lain tulisan Romaeti (2011) lebih berfokus pada premispremis yang dilontarkan Ustadz Jefri al-Bukhari 
mengenai pacaran, khususnya berkaitan dengan dampaknya terhadap moralitas remaja. Rahayu (2015) mengkaji relasi pacaran melalui sudut pandang pendidikan Islam. Pratiwi (2012) lebih berfokus pada gambaran dan perilaku pacaran pada fase remaja awal. Muslimah (2013) mengkaji tentang relasi ekspresi cinta dalam pacaran pada remaja yang menempuh pendidikan di Madrasah Tsanawiyah. Indrayani (2016) membahas mengenai perilaku berpacaran remaja di Desa Batubelah, Kecamatan Kampar, Kabupaten Kampar.

Lebih jauh artikel ini lebih berfokus pada anatomi konflik yang terjadi dalam hubungan pacaran baik pada remaja maupun dewasa. Anatomi konflik ini mengambil wujud baik kekerasan verbal maupun fisik dalam hubungan pacaran yang akan dikaji lebih jauh. Tidak hanya itu saja, tapi juga berupaya menghasilkan formulasi penyelesaian konflik dari berbagai konflik yang terjadi dalam hubungan pacaran sesuai derajat-derajat tertentu.

Secara sosiologis, "kekerasan" diartikan sebagai "agresi jahat yang tidak terukur" (Ray, 2014). Agresi ini seringkali tidak hanya menimbulkan korban luka, tetapi juga korban jiwa. Dalam ranah keilmuan sosial-humaniora, kekerasan setidaknya mengambil tiga bentuk; kekerasan simbolis, kekerasan verbal, serta kekerasan fisik. Kekerasan simbolis umumnya hadir melalui kode-kode atau tanda citra visual, sebagai misal, citra-citra yang mengintimidasi diri kita. Kekerasan verbal mewujud dalam perkataan lisan atau wicara yang menyakiti perasaan, atau bisa juga ungkapan-ungkapan yang sesungguhnya tidak patut dan tidak layak untuk dikatakan berdasarkan takaran nilai, norma, dan budaya suatu masyarakat. Terakhir, kekerasan fisik, adalah bentuk "ancaman terhadap tubuh"; kekerasan fisik menimbulkan rasa sakit terhadap tubuh, dapat membekas ataupun tidak, tetapi umumnya membekas (Bourdieu, 2009).

Sementara itu pacaran dapat diartikan sebagai relasi sosial intim (dekat) antara dua individu berlawanan jenis yang bertujuan untuk mencari kesesuaian diri satu sama lain guna menuju kehidupan berkeluarga (Sharma, 2015). Fenomena pacaran adalah budaya yang awalnya ditemui pada masyarakat Barat, namun kini turut membudaya pada masyarakat Timur. Umumnya, mereka yang menjalin relasi pacaran adalah individu yang telah dewasa dan akan melangsungkan kehidupan berkeluarga, tetapi kini pacaran juga dilakukan oleh remaja, bahkan anak-anak. Lebih jauh, perkembangan studi gender menyebabkan definisi mengenai "pacaran" saat ini perlu dirubah. Dengan diakuinya "jenis kelamin ketiga" yang sedikit-banyak terrepresentasi lewat hadirnya kelompok sosial LGBT (Lesbian, Gay, Biseksual, dan Transgender), pacaran tidak lagi hanya bisa diasosikan bagi mereka dua individu yang berlawanan jenis, tetapi juga sesama jenis (Barker, 2009). Dalam artikel ini, definisi pacaran yang digunakan tetap mengacu pada relasi antara dua individu berlawanan jenis, yaitu laki-laki dan perempuan.

Sedangkan anatomi konflik terdiri dari istilah anatomi dan konflik. istilah "anatomi" berasal dari bahasa Yunani yang berarti "memotong". Dalam ilmu pengetahuan modern, anatomi berkaitan dengan cabang disiplin biologi yang berkenaan dengan struktur berikut organ(isasi) makhluk 
hidup. Lebih jauh, istilah ini kerap diasosiasikan dengan studi zootomi (anatomi hewan) dan fitotomi (anatomi tumbuhan). Dalam ranah keilmuan sosial, istilah anatomi digunakan untuk menunjuk struktur dan pola-pola interaksi antarindividu. Hal ini sebagaimana pendefinisian sosiologi oleh Walter dan Crook (dalam Usman, 2004): "Sociology is the systematic analysis of the structure of social behavior" ["Sosiologi adalah analisis sistematis mengenai struktur perilaku sosial']. Pola perilaku yang berstuktur sebagaimana dimaksudkan di sini adalah perilaku yang diulang-ulang sehingga menunjukkan pola-pola tertentu.

Secara sosiologis, "konflik" diartikan sebagai suatu proses sosial antara dua orang atau lebih (bisa juga kelompok) di mana salah satu pihak berusaha menyingkirkan pihak lain dengan cara menghancurkan atau membuatnya tidak berdaya (Zeitlin, 1973). Kadar konflik dalam ranah sosial berbeda-beda, yakni dari persaingan, pertentangan, perselisihan, kontravensi, diskonformitas, hingga kekerasan. Namun dalam ranah sosial, konflik menjadi hal yang wajar mengingat setiap individu memiliki pemikiran dan perasaannya tersendiri, sehingga gesekan atau benturan pemikiran berikut perasaan (baca: kepentingan) tersebut menjadi tidak terhindarkan. Hanya saja, konflik yang terjadi menjadi tidak wajar apabila berekses pada kekerasan mengingat hal tersebut dapat melukai fisik bahkan menghilangkan nyawa seseorang. Berdasarkan paparan di atas, istilah "anatomi konflik" yang dimaksudkan di sini adalah struktur atau pola konflik yang timbul dalam relasi pacaran.

Artikel ini memakai perspektif konflik George Simmel, Lewis Coser, sosiologi eksistensialisme
Jean Paul Sartre mengenai cinta. Bagi Simmel, apabila konflik adalah salah satu wujud relasi sosial, maka seharusnya konflik pun bersifat asosiatif (kerjasama). Dimensi kerjasama dalam konflik menurut Simmel adalah upaya setiap pihak untuk mengeliminasi yang lain. Sebagai misal, apabila dalam perusahaan membutuhkan satu karyawan baru, sedangkan terdapat tiga orang pelamar, maka ketiga orang tersebut sebetulnya sedang saling bekerjasama untuk mengenyahkan yang lain. Di samping itu, keberadaan individu lain dalam kompetisi memberikan kesempatan bagi individu untuk menunjukkan kelebihan diri dibandingkan individu lain. Hal ini tentu tidak dapat terjadi tanpa adanya persaingan dengan individu lain, oleh karenanya, konflik pun adalah bentuk kerjasama menurut Simmel (Zeitlin, 1973; Poloma, 1979).

Pemikiran konflik Coser menyatakan bahwa konflik akan berdampak positif sejauh tidak menyinggung "tema inti". Tema inti yang dimaksud Coser adalah perihal sensitif, umumnya persoalan-persoalan personal yang begitu membekas bagi individu dan akan menyulut emosi individu terkait apabila seseorang menyinggungnya. Dengan demikian, tema inti bagi setiap individu berbeda-beda, hal ini seperti sebabsebab tertentu dan spesifik yang bisa membuat individu tersulut amarahnya. Namun demikian menurut Coser, sejauh konflik yang terjadi tidak menyinggung tema inti, ini akan baik bagi relasi antarindividu. Seringkali konflik diperlukan untuk lebih memahami karakter antarindividu (Zeitlin, 1973; Poloma, 1979).

Pemikiran sosiologi eksistensialisme Jean Paul Sartre mengenai cinta cenderung bersikap pesimis atasnya. Sartre mendaulat cinta sebagai 
kegagalan individu mempertahankan dirinya sebagai subjek. Sartre juga mengatakan bahwa eksistensi cinta tidak lebih sebagai bukti "terjebak pada dunia orang lain". Bagi Sartre, dimensi ketertindasan cinta terletak pada berbagai tuntutan yang dimiliki satu pasangan terhadap pasangan lainnya, inilah mengapa Sartre menyebut cinta sebagai "penjara halus". Kepesimisan Sartre terhadap cinta juga ditunjukkan lewat pemikirannya ihwal cinta sebagai objektivasi terhadap orang lain. Dalam cinta, yang terjadi adalah hukum "menindak" ataukah "ditindak" sehingga salah satu akan lebih dominan terhadap lainnya, dan memang menurut Sartre, sejak awal pertemuan antarmanusia menemui wujudnya sebagai konflik (Nugroho, 2013).

Artikel ini bersifat deskriptif-eksplanatif yang lebih menekankan pada proses dan kedalaman analisis atas data. Lebih jauh, deskriptif bermaksud berupaya menggambarkan fenomena yang terjadi, sedangkan eksplanatif berupaya menjelaskan fenomena yang ada baik secara sebab-akibat, interpretatif, ataupun diakronik. Artikel ini berlatar alamiah, menggunakan narasi sebagai data, dan interpretasi sebagai teknik analisis. Di samping itu, sebagaimana pemahaman tentang pendekatan kualitatif pada umumnya, artikel ini tidak ditujukan untuk menggeneralisir atau menciptakan premis-premis universal atas suatu fenomena (Moleong 2011).

\section{Cinta Didefinisikan Kembali}

Banyak para figur dan tokoh ilmu sosialhumaniora berusaha mendefinisikan kata "cinta". Kahlil Gibran misalnya, menyebut cinta sebagai sesuatu yang menggetarkan. Jean-Paul Sartre menyebut cinta sebagai "keyakinan yang buruk".
Erich Fromm mendaulat cinta sebagai "modus menjadi" ketimbang "memiliki", serta Thomas Hobbes yang menganggap cinta tidak lebih sebagai reaksi kimia tubuh manusia semata (Martin, 2018). Lebih jauh akan terlihat berbagai perspektif subjektif mengenai "cinta". Pendefinisian "cinta" tentu sangat penting mengingat cara mendefinsikan sesuatu, berdampak besar pada bagaimana sikap atau tindakan mengenainya.

CMA (21) mendefinisikan cinta sebagai,

"Cinta itu kayak dua orang yang saling suka, saling pingin menjaga. Terus cinta itu datang dengan sendirinya aja gitu, tiba-tiba aja dia, misalnya nih aku suka sama dia, kayak nyaman terus tiba-tiba aja jatuh cinta gitu."

Uniknya pendefinisian cinta menurut CMA adalah seolah cinta sebagai perasaan yang muncul secara tiba-tiba atau begitu saja. Padahal, gejala semacam ini nyaris musykil. Cinta pada pandangan pertama misalkan, faktual juga disebabkan secara inderawi, karena melihat lawan jenis yang cantik atau tampan, hanya saja, perasaan cinta seperti itu bisa didaulat lebih didominasi oleh nafsu. Sebetulnya, jatuh cinta selalu memiliki alasan, hanya saja seringkali pelaku tidak mengetahui atau tidak menyadarinya. Dalam kasus CMA misalkan, perilaku saling suka pastinya diawali oleh sesuatu atau sebab tertentu.

PPD (21) mendefinisikan cinta sebagai berikut, "Cinta ya, itu kalau menurut aku tindakan saling memberi dan saling mengasihi."

PPD mengambil definisi cinta yang cukup umum, yakni sebentuk tindakan saling memberi dan mengasihi. Di sini, cinta menurut PPD sebetulnya cukup bersyarat, yakni ada sesuatu 
yang diberi, dan ada sesuatu yang diterima. Dengan demikian, cinta menurut pendefinisian PPD menutup kemungkinan cinta yang tidak berpamrih.

Menurut Munir (21), cinta adalah,

"Pada dasarnya cinta engga boleh terbagi pada yang lainnya, kita akan terfokus pada satu orang. Ada kasih, ada sayang, ada pemurah."

Munir lebih menekankan cinta dalam perspektif monogami, yakni cinta yang berfokus pada satu lawan jenis. Di samping itu, terdapat pula syarat cinta menurutnya, yakni; kasih, sayang, dan pemurah. Pendefinisian cinta menurut Munir menyangkal bentuk-bentuk ketegasan sebagai salah satu bentuk cinta. Padahal, pada momen-momen tertentu ketegasan — juga kedisiplinan - diperlukan dalam cinta.

Bagi AZM (23) cinta adalah "Saling menerima kelebihan dan kekurangan masing-masing."

AZM turut mengambil pendefinisian cinta yang cukup umum. Pendefinisian cinta oleh AZM dapat dengan mudah ditemui dalam berbagai konstruksi budaya pop. Namun, konstruksi cinta yang disebutkan AZM dirasa lebih masuk akal dan dewasa dibandingkan beberapa pendefinsian cinta oleh para informan lainnya. Hal ini mengingat AZM tidak melupakan dimensi "dialog" dalam cinta.

Menurut Fiqri (24), cinta adalah "Understanding other, saling memahami lah karena pengertiannya kek gitu yang paling dimengerti."

Pendefinisian cinta oleh Fiqri memiripkan bentuknya dengan AZM, yakni menekankan pada aspek dialogis. Di balik kalimat understanding other sesungguhnya tersirat kepentingan untuk memenuhi kebutuhan satu sama lain. Dalam hal ini, "saling memahami" tidak hanya menjadi sebuah konsep, tetapi "tindakan" untuk dipraktikkan.

\section{Cinta pada Pasangan, Teman, dan Keluarga}

Bahasa Yunani Kuno mempunyai definisi yang cukup kaya mengenai cinta. Dalam bahasa Yunani Kuno, cinta adalah sophein. Lebih jauh, sophein dibagi menjadi tiga, yakni; agape, philia, dan eros. Agape lebih condong pada cinta terhadap keluarga, agape dinilai bentuk cinta yang paling tinggi karena tidak melihat fisik dan asal-usul seseorang. Philia lebih kepada cinta terhadap sahabat atau teman, sedangkan eros adalah cinta romantis antarlawan jenis, yakni cinta yang penuh nafsu (Martin, 2018). Sementara, dalam bahasa Indonesia, pengertian cinta agaknya tidak terlalu kaya. Umumnya, cinta selalu didefinsikan dalam bentuk cinta eros, yakni cinta yang ditujukan pada lawan jenis. Lebih jauh, kita akan melihat bagaimana para informan membedakan antara cinta dengan pasangan, teman, dan keluarga.

CMA (21): “... beda pasti, kalo misalnya keluarga kan kayak dari lahir itu udah sayang sama kita, kalo sama pacar kan kayak masih masa-masa puber gitu lho baru mengenal cinta pada lawan jenis. Kan kalau misalnya sama keluarga kan gak cuma lawan jenis aja, itu kan kayak keluarga gitu."

Pengertian cinta pada keluarga menurut CMA sedikit-banyak sesuai dengan karakter agape, yakni cinta yang tidak melihat fisik, jenis kelamin, atau asal-usul seseorang. Cinta yang memang 
sudah semestinya diarahkan untuk mencintai, atau dengan kata lain: "Cinta untuk cinta". Menariknya, CMA mendefinisikan cinta eros berdasarkan periodesasi waktu, yakni baru muncul di masa pubertas.

PPD (21): "...iya beda, kalau sama orangtua ni kan seandainya kita dimarahain itu artinya kan rasa cinta orantua terhadap kita. Kalau sama pacar kan biasanya itu yang saling suka, saling sayang. Terus yang ngebedain lagi cara orangtua ngerawat itu kan juga termasuk rasa cinta."

Pernyataan PPD seolah mengambil garis pemisah yang tegas antara cinta keluarga dengan pacar, yakni "kemarahan" sebagai ihwal yang wajar dalam cinta keluarga (orangtua), sementara hal itu dianggap tidak wajar dalam hubungan pacaran. Di sini, PPD menutup kemungkinan kemarahan sebagai bentuk cinta dan sayang dalam hubungan pacaran.

Tobel (22): “... ya itu dia.. kan kayak tulus banget gitu kan, kayak kalau sama pacar gua sendiri ke dia, dibuat-buat aja gitu, 'oh pedoman bercinta itu kayak gini-gini', 'jadi aku harus kayak gitu' kayak seragam gitu kayak orang orang kayak harus jalan, ngedate gitu gitu. (jadi bagi dia pacaran dan cinta itu cuma sekedar pedoman untuk membuat seragam gimana bertingkah laku ketika punya pasangan) ... kalau ama keluarga mah sih kayak tulus, tulus aja gitu rasanya. kayak gua demen artinya gua cinta sama keluarga gua."

Hal menarik dari perbedaan antara cinta pada pasangan dengan cinta pada keluarga menurut Tobel di atas adalah, dalam cinta pasangan (pacar), ia serasa terdapat standar yang jelas tentang bagaimana seharusnya seseorang melakukan hubungan pacaran dengan lawan jenis.
Dengan kata lain, terdapat patokan atau ukuranukuran tentang bagaimana seharusnya "kegiatan berpacaran" dilangsungkan. Hal ini juga menyiratkan cinta sebagai sesuatu yang bersyarat, yakni; jalan-jalan (ngedate), nonton, dan lain sejenisnya. Pandangan cinta pada pasangan menurut Tobel dapat pula disebut "cinta yang terbirokrastiskan" dan terukur. Sementara, pandangan cintanya terhadap keluarga adalah ihwal yang tidak bersyarat dan tidak terstandarisasi, yakni cinta sebagai cinta.

Munir (21): “... bedanya di proporsi. Mungkin kalau lebih ke keluarga itu bukan bentuk cinta tapi bentuk kasih."

Boleh jadi, apa yang dimaksudkan Munir adalah "porsi" atau besaran jumlah cinta yang dicurahkan. Baginya, secara tersirat, cinta terhadap pasangan mempunyai porsi atau batasanbatasan, sedangkan cinta pada keluarga tidak berporsi dan sama sekali tidak terbatas. Pernyataan Munir menunjukkan secara jelas bahwa ia bisa lebih memilih keluarga ketimbang pasangan. Bahkan lewat pernyataannya, kiranya pasangan dianggap sebagai sosok yang asing, dengan demikian agaknya menjadi cukup pesimis mengharapkan cinta yang menyatu dalam pandangan Munir, sementara: "In love, one and one are one", menurut Jean-Paul Sartre.

AZM (23): “... membedakan kasih sayang? Bisalah. Yang membedakan mungkin saat ditinggalkan yang paling mencolok."

Ungkapan AZM cukup unik, baginya perbedaan antara cinta pada pasangan dengan cinta keluarga barulah diketahui atau bisa diidentifikasi pada momen-momen tertentu, yakni ketika dirinya ditinggal kekasih. Secara tidak langsung, 
AZM hendak berkata bahwa keluarga tidak mungkin meninggalkannya, atau memiliki cinta yang abadi-tidak lekang waktu. Sementara, cinta kekasih bersifat temporer atau sementara; sang kekasih tidak lagi mencintainya ketika meninggalkannya. Hal ini agaknya juga berlaku sebaliknya bagi AZM. Cintanya pada keluarga tidak lekang waktu, sedangkan cintanya pada pasangan bisa dibatasi oleh waktu.

\section{Cinta Tidak Serius dan Cinta Serius}

Upaya guna mendefinisikan "cinta tidak serius" akan lebih baik dilakukan apabila terlebih dahulu kita mendefinisikan apa itu "cinta yang serius". Cinta serius sebagaimana dimaksudkan di sini adalah cinta yang berwawasan ke depan, bisa berupa hubungan pacaran atau bukan pacaran yang tertuju pada pernikahan untuk membina hubungan keluarga dan berketurunan. Sebaliknya, "cinta tidak serius" dapat diterjemahkan sebagai kebalikan dari kualitas-kualitas yang terdapat pada cinta serius. Umumnya, cinta tidak serius urung berwawasan ke depan, bersifat dangkal, dan sekadar mengedepankan aspek afeksi atau emosi. Dengan demikian, cinta yang demikian bersifat irasional, banyak orang menyebutnya sebagai "cinta monyet" atau "cinta anak kecil".

Cinta serius maupun cinta tidak serius dialami dalam waktu yang berbeda-beda. CMA (21) mengatakan untuk pertama kalinya merasakan cinta tidak serius pada kelas 2 SMP. Menurutnya, cinta yang tidak serius adalah cinta yang sekadar disebabkan oleh kekaguman semata, sebagaimana yang dialaminya pada kelas 2 SMP. Namun saat ini, di bangku kuliah, ia mengatakan bahwa telah memiliki cinta serius. Ihwal menarik dari pernyataannya adalah, "... kalau yang ini sudah satu agama". Ini artinya, CMA menjadikan agama yang sama sebagai salah satu tolak ukur cinta yang serius. Dengan kata lain, apabila tidak satu agama yang sama, maka cinta itu belumlah serius. Di samping itu, CMA mengaku juga telah membicarakan hubungan pacarannya hingga jenjang pernikahan. Hal lain yang menurutnya menjadikan hubungan yang sekarang sebagai cinta yang serius adalah adanya kedewasaan. Sebagai misal, dahulu ia harus terlebih dahulu meminta izin kepada orangtua, sedangkan sekarang tidak perlu lagi.

PPD (21) untuk pertama kalinya mengalami cinta yang tidak serius saat duduk di bangku SMA. Ia pun mengakui bahwa hubungannya dengan pasangan kala itu tidaklah serius, bahkan PPD secara tegas menyebutnya sebagai "cinta monyet". Keputusan untuk tidak menyeriusi hubungan yang ia jalani dikarenakan melihat karakter pasangan yang posesif. Sementara untuk saat ini, PPD sama sekali belum menjalin cinta yang serius. Menurutnya, cinta yang serius adalah cinta yang penuh komitmen, tidak peduli jarak jauh/dekat memisahkan. Di samping itu, tolak ukur cinta yang serius menurut PPD adalah keberanian setiap pihak (pasangan) untuk menghadap orangtua masing-masing.

Berbeda dengan CMA dan PPD, Tobel (22) telah merasakan cinta yang tidak serius saat duduk di bangku SD. Dia terkesan cukup kesulitan menjelaskan atau mengartikulasikannya. Apa yang ditegaskan olehnya adalah, kala itu ia sekadar melihat paras cantik dari lawan jenis, dan sekadar menyukainya begitu saja. Di 
bangku SMP, Tobel juga kembali terlibat hubungan cinta yang tidak serius, ia pun masih menggunakan tolak ukur yang sama, yakni kecantikan paras lawan jenis. Namun menurutnya, cinta yang serius adalah cinta yang telah memiliki arah dan tujuan, di samping itu ia juga mengatakan bahwa cinta yang serius adalah "cinta yang membuat kita merasa pasangan menjadi bagian dari diri kita, dan ingin menghabiskan hidup bersamanya".

Munir (21) untuk pertama kalinya merasakan cinta yang tidak serius saat duduk di bangku SMA. Menurutnya, apa yang ia rasakan kala itu hanyalah kebahagiaan; bahagia menyukai pasangan, bahagia bertemu pasangan, juga bahagia menghabiskan waktu bersama pasangan. Namun ia mengatakan jika dalam hubungan itu ia tidak melibatkan perasaan yang mendalam. Hal ini baru ia lakukan ketika menginjak bangku kuliah, yakni kali pertama pengalamannya merasakan cinta serius. Akan tetapi, perasaan cinta seriusnya pada lawan jenis faktual tidak dimotivasi oleh faktor antroposentris semata, yakni hubungan antarmanusia an-Sich, melainkan karena ia melihat lawan jenis tersebut begitu taat beragama. Di sini, cinta yang serius menurut Munir berkaitan dengan tata cara beragama kehidupan sehari-hari, yakni ia ingin menikah (baca: didampingi) oleh sosok yang juga bisa membimbingnya dan menjadikannya manusia lebih baik.

Perspektif cukup menarik hadir dari AZM (23), menurutnya cinta monyet atau cinta yang tidak serius tidaklah bisa dikategorikan sebagai cinta. Lebih jauh menurutnya, cinta yang tidak serius sekadar didasarkan pada kekaguman dan hasrat untuk memiliki. Sementara menurutnya, cinta yang serius adalah cinta yang tidak sekadar pacaran, tetapi juga sudah membincangkan pada jenjang yang lebih tinggi, yakni pernikahan. Pendefinisian AZM tentang cinta serius kiranya memiripkan dengan pendefinisiannya secara umum. Berbeda halnya dengan beberapa informan sebelumnya, AZM mengaku telah mengalami cinta serius sejak duduk di bangku kelas 3 SMP, kemudian juga saat duduk di bangku SMA. Dapatlah ditilik, perspektif cinta menurut AZM agaknya cukup serius, ia menolak pendefinisian pacaran sebagai tindakan mainmain atau coba-coba. Baginya, apabila demikian, maka itu belumlah disebut pacaran.

\section{Konflik dalam Pacaran}

Konflik adalah sesuatu yang wajar dalam setiap interaksi sosial. Secara sosiologis, konflik diartikan sebagai proses sosial di antara dua orang atau lebih di mana salah satu pihak berupaya menyingkirkan pihak lain dengan cara menghancurkan atau membuatnya tidak berdaya. Penyebab utama terjadinya konflik adalah perbedaan sudut pandang dan kepentingan. Hal ini umum mengingat setiap individu memiliki pemikiran dan perasaan yang berbeda-beda, sehingga persinggungan antarsatu sama lain pun tidak terhindarkan. Lebih jauh, pacaran sebagai bentuk interaksi antara kedua belah pihak yang umumnya berlawanan jenis pun tidak pernah terlepas dari konflik, baik dalam skala kecil maupun skala besar. Skala besar semisal hingga membuat pasangan mengakhiri hubungan, atau ketika konflik berujung pada kekerasan. 
CMA (21) mengatakan bahwa konflik atau pertengkaran yang terjadi antara dirinya dengan pasangan biasanya disebabkan oleh hal-hal kecil. Semisal, penggunaan nada tinggi dalam komunikasi sehingga satu sama lain saling berbalas nada tinggi. Lebih jauh ia mengakui, ketiadaan waktu dirinya bagi pasangan juga menjadi sebab pertengkaran yang sering terjadi, bahkan hingga pasangannya meminta putus. Namun demikian menurut CMA, pada akhirnya pasangannya lah yang meminta maaf dan mengoreksi kata-katanya. Begitu pula yang dialami PPD (21), konflik yang terjadi antara dirinya dengan pasangan umumnya juga disebabkan oleh persoalan waktu, terutama dirinya yang tidak sempat membalas BBM (Black Berry Messenger). Umumnya, bentuk konflik yang terjadi antara PPD dengan pasangannya adalah saling mendiamkan. Dalam hal ini, PPD lah yang harus selalu terlebih dahulu menghubungi pasangannya.

Penggunaan nada keras pada pasangan sudah tentu menemui wujudnya sebagai konflik. Secara sadar maupun tidak sadar, cara tersebut digunakan untuk menyingkirkan atau membuat tidak berdaya salah satu pihak. Dalam konteks ini adalah mengeliminasi argumen atau pendapat pihak lain sehingga pendapat pelakulah yang dominan. Di satu sisi, mendiamkan pasangan, secara sosiologis, juga termasuk dalam interaksi sosial mengingat diam sendiri adalah respon terhadap perkataan atau perilaku pihak lain. Sikap diam yang dilakukan di sini sesungguhnya juga tidak terlepas dari agresi, yakni bagaimana emosi negatif individu mewujud lewat kekuataannya membuat orang lain "seakan tidak ada" melalui kebisuannya. Dengan kata lain, "diam" sekadar mengambil wujud lain dari kemarahan, dan ini seturut dengan ungkapan Simmel (dalam Wolff, 1950) tentang konflik sebagai upaya untuk mengeliminasi (meniadakan) salah satu pihak

Cukup berbeda dari CMA dan PPD, konflik yang dialami Tobel (22) dengan pasangan biasanya dikarenakan saling cemburu. Namun uniknya, Tobel selalu memiliki cara agar pasangan tidak marah berkepanjangan, ia biasa membuat kejutan-kejutan agar pasangan melupakan kemarahannya. Berbeda dengan pasangan PPD, apabila sedang marah, pasangan Tobel terus-menerus membahas persoalan yang membuatnya marah, inilah mengapa Tobel harus selalu mencari cara agar pasangan melupakan kemarahannya. Berbeda dengan beberapa informan sebelumnya, konflik yang dialami Munir (21) lebih sering disebabkan oleh agama yang berbeda dengan pasangannya. Pada awalnya, intensitas konflik cukup keras, namun lamakelamaan tensi konflik dapat menurun dikarenakan pasangan Munir tidak lagi mendengarkan "kicauan" orangtuanya ihwal larangan pacaran dan menikah berbeda agama. Di samping itu, konflik yang dialami Munir dan pasangan juga kerap diakibatkan oleh rasa cemburu. Terkait hal ini, Munir menganggapnya wajar karena menurutnya justru cemburu itu menunjukkan rasa cinta.

Apa yang dilakukan Tobel di atas sebagaimana kajian Sartre (1956) mengenai berbagai "tuntutan dalam cinta". Meskipun pasangan Tobel tidak menuntut dirinya untuk memberi hadiah, namun bagaimanapun juga inisiatif Tobel di- 
motivasi oleh kemarahan pacaranya. Dengan kata lain, ia melakukan itu bukan dikarenakan dirinya sendiri, melainkan orang lain-pacarnya. Itulah mengapa, Sartre mengatakan hubungan antarindividu yang dilandasi cinta sesungguhnya nausea 'memuakkan' karena merubah struktur being for itself (berada bagi dirinya) menjadi being for others (berada untuk orang lain), tidak jarang, justru membuat eksistensi manusia menjadi being in itself (berada dalam dirinya) layaknya sebuah "benda".

Adapun konflik yang sering terjadi antara Munir dengan pasangannya akibat rasa cemburu sebagimana diutarakan Sartre (1956) bahwa pada akhirnya cinta akan menjelma menjadi "hasrat untuk memiliki". Dalam kondisi demikian, manusia kehilangan dirinya sebagai subjek dan sekadar menjadi objek orang lain. Dalam kondisi tertentu, hal tersebut dapat sekadar mereduksi manusia sebagai "daging" semata. Ini dikarenakan, rasa posesif menyiratkan ketidaksimpatian terhadap perasaan dan pemikiran orang lain Itulah mengapa, Sartre berkata, "Hasrat selalu gagal menemukan dirinya sebagai subjek". Subjek yang dilingkupi hasrat akan memiliki kesadaran nonreflektif, baik bagi dirinya sendiri maupun orang lain. kesadaran nonreflektif adalah tipe kesadaran yang selalu meniadakan subjek dan menggantinya dengan objek.

AZM (23) mengaku cukup jarang bertengkar dengan pasangannya. Tetapi sama seperti para informan sebelumnya, awalnya pertengkarannya dengan pasangan selalu dimulai lewat chat, kemudian telpon, dari telpon biasanya kedua belah pihak sepakat untuk bertemu keesokannya guna menyelesaikan masalah. Satu hal menarik yang diungkap AZM dalam pertengkaran adalah self restraint atau "menahan diri". Ia biasa menahan emosi, dan baru mengungkapnya ketika bertemu pasangan. Adapun penyebab pertengkarannya dengan pasangan biasanya disebabkan oleh AZM yang merasa terlalu dikekang oleh pasangannya. AZM mengungkap bahwa pasangannya selalu hendak mengikuti kemana pun dirinya pergi; saat hendak pergi bersama teman-temannya, ngobrol bersama teman-temannya; tidak jarang pula ia kerap dilarang pergi, ini-itu, dan lain sebagainya.

Konflik yang dialami AZM tidak hanya bersifat realistis dalam pandangan Coser (dalam Poloma, 1979), tetapi bisa juga merambah ke konflik yang bersifat nonrealistis. Konflik realistis dalam hal ini adalah konflik langsung antara AZM dengan pasangannya, sedangkan konflik nonrealistis adalah potensi konflik yang bisa terjadi antara pasangan AZM dengan kawan-kawan AZM. Dalam hal ini, kawan-kawan AZM yang sesungguhnya tidak memiliki kepentingan atau masalah apa pun dengan pasangan AZM, dapat menciptakan konflik baru. Apa yang dilakukan AZM dengan cara menahan diri agaknya sudah tepat, karena hal itu akan menggiring pada konflik realistis tanpa antagonisme, yakni bagaimana AZM sekadar memainkan status dan perannya sebagai seorang kawan bagi teman-temannya, dan seorang pacar bagi pasangannya.

\section{Kekerasan dalam Pacaran; Simbolik, Verbal, dan Fisik}

Secara sosiologis, kekerasan adalah tindakan agresi yang dimaksudkan untuk menyebabkan penderitaan atau menyakiti orang lain. Lebih jauh, 
kekerasan tidak hanya megambil menifestasi secara fisik, tetapi juga verbal dan simbolik. Kekerasan verbal adalah kekerasan yang disebabkan oleh perkataan kasar lawan bicara sehingga menyakiti perasaan. Sedangkan kekerasan simbolik mewujud lewat gestur yang mengintimidasi. Sebagai misal tatapan mata (cara menatap), bahasa tubuh, dan lain sejenisnya. Dalam subbab ini kita akan menilik dan mengulas berbagai bentuk kekerasan yang pernah dialami informan selama membina hubungan pacaran dengan pasangan.

CMA (21) pernah mengalami kekerasan simbolik, yakni ketika pasangan memberinya gestur acuh tidak acuh dikarenakan sedang bertengkar. Di samping itu, ia pernah pula menerima kekerasan verbal berupa kata-kata kasar dari pasangannya, yakni ketika pacarnya meluapkan kemarahan padanya. Bahkan, CMA juga pernah menerima kekerasan fisik dari pacarnya. Terkait hal ini, pacar CMA menganggapnya sebagai candaan, namun hal tersebut tidak sebagaimana penerimaan CMA dan kawan-kawan CMA. Pernah suatu kali, sang pacar memukulmukul kepala CMA, sontak tindakan tersebut menjadi perhatian orang-orang di sekitarnya.

Kekerasan fisik yang dituai CMA dari pacarnya, sebagaimana ungkap Sartre (1956) tentang bagaimana individu bisa berubah menjadi objek semata dalam hubungan cinta. Tentu, CMA mengalami penindasan di sini, ia menuai pengalaman eksistensial berupa keluar dari "kemungkinan-kemungkinan diri" karena tidak menyangka bakal menuai kekerasan fisik dari pacarnya di tempat umum. Ia sama sekali kehilangan kendali atas dirinya dan pacarnya, pengalaman ini pun dapat memicu kegelisahan dan ketakutan setelahnya. Di samping itu, karena tindakan itu dituainya di tempat umum, maka CMA pun mengalami momen eksistensial berupa "rasa malu". Dalam pandangan Sartre, rasa malu muncul lewat tatapan mata orang lain, yakni bagaimana lewat tatapan orang-orang di sekitar CMA, CMA diminta untuk menilai dirinya sendiri. Implikasi yang terjadi akibat pengalaman ini adalah, CMA justru akan semakin intim dengan dirinya sendiri, dan bukan dengan pasangannya.

Pada awalnya, PPD (21) menganggap tidak pernah merasa menuai kekerasan dari pacarnya. Memang, ia tidak pernah menuai gestur yang mengintimidasi dari pacarnya, kata-kata kasar, juga kekerasan fisik dalam bentuk apa pun. Namun kemudian, ia berpikir jika tindakan posesif sang pacar juga bisa dikategorikan sebagai bentuk kekerasan, tepatnya kekerasan psikis. Di sini, PPD tidak menganggap perhatian berlebih dari sang pacar sebagai bentuk cinta dan sayang, hal tersebut justru ia terima secara sebaliknya: menyiksa. Terkait kekerasan dalam pacaran, ia berkomentar bahwa jika telah terjadi kekerasan dalam segala bentuknya, maka hubungan itu sudah tidak sehat. Lebih jauh menurutnya, hubungan cinta atau pacaran tidak sekadar melibatkan dua pihak-antara pria dengan wanita semata-tetapi juga orang-orang di sekitar mereka, yaitu keluarga, teman-teman, dan lain sebagainya.

Tobel (22) pernah mengalami kekerasan verbal dari pacarnya, yakni ketika dia menuai kata-kata "Goblok banget sih kamu!" dari pacarnya. Bahkan, ia mengatakan jika kerap menuai perkataan kasar dengan nada tinggi dari 
pacarnya. Di samping itu, ia juga pernah mengalami kekerasan fisik yakni ketika "tabokan" pacarnya dianggap keterlaluan. Ungkapnya, hal itu terjadi dikarenakan sang pacar cemburu. Tobel mengakui jika ia cenderung merasa takut pada pacarnya. Itulah mengapa ia lebih sering memilih diam ketika pacarnya sedang marahmarah. Begitu juga, Tobel lebih banyak menyerahkan berbagai keputusan pada pacarnya, sementara dia mengikutinya begitu saja Meskipun berbagai pengalaman tidak mengenakkan dituai Tobel, namun ia mengaku tidak pernah berniat memutuskan pacaran. "Sudah sama dia, ya sama dia aja", ucapnya.

Munir (21) pernah menuai kekerasan simbolik dan verbal dari pacarnya, tetapi ia menganggapnya sebagai bentuk "penyadaran" bagi dirinya. Dengan kata lain, ia menempatkan kekerasan verbal yang diberikan pacarnya sebagai nasehat dan wujud perhatian agar dirinya menjadi lebih baik. Umumnya, cara pandang Munir hanya bisa terjadi pada orang-orang yang mudah merasa bersalah, dan pada batas-batas tertentu mengidap masokhisme. Di sisi lain, apa yang dilakukan Munir adalah wujud manipulasi dirinya terhadap realitas. Hal ini bisa dijelaskan lewat teori "kesadaran yang terbagi" dari Alfred Schutz (1995). Apabila seseorang tidak mampu menerima atau menghadapi realitas puncak, ia akan membuat "makna-makna khusus" untuk menegaskan bahwa semuanya baik-baiksaja.

Di sisi lain, apa yang dialami Munir bisa juga dijelaskan lewat pemikiran Sartre (1956) mengenai mauvaise foi atau "keyakinan yang buruk". Sartre menggunakan istilah ini untuk menjelaskan fenomena serupa seperti yang dimaksudkan
Marx dengan false consciousness kesadaran palsu', Antonio Gramsci dengan "hagemoni", atau Herbert Marcuse dengan istilah "desublimasi represif'; intinya fenomena ketertindasan individu atau kolektif yang tidak disadari atau tidak dianggapnya sebagai ketertindasan. Sartre mengungkap mungkinnya hal ini terjadi akibat "balutan-balutan halus" dalam interaksi antarmanusia, seperti bagaimana cinta dan kasih sayang menjadi selubung yang menyamarkan agresi manusia.

Boleh jadi, pengalaman yang menimpa AZM (23) terbilang paling ekstrim. Ia sempat diancam akan dipukul dengan botol kaca oleh pacarnya. Pernah pula, pacarnya memegang botol pecah dan mengancam akan bunuh diri apabila AZM memutuskan hubungan mereka. Di sisi lain, berbagai problem yang terjadi antara AZM dan pacarnya dikarenakan sang pacar terlalu mengekang dirinya menurut AZM. Sebagai misal, keharusan pergi keluar ditemani sang pacar, dengan kata lain, AZM tidak boleh pergi bersama temantemannya (boleh asalkan ditemani sang pacar). Dijelaskan oleh AZM, biasanya setelah sang pacar meluapkan kemarahan, pacarnya itu sendirilah yang seketika meminta maaf setelahnya. Di sini, dapat ditilik psikologis pacar AZM cukup mengkhawatirkan. Beruntung, AZM pada akhirnya bisa memutuskan pacarnya. Namun itu pun ia lakukan dengan strategi yang sangat matang untuk menghindari hal-hal di luar prakiraan-di luar akal sehat—yang bisa timbul dari sang pacar.

Apa yang dialami AZM dalam pandangan sosiologi eksistensialisme Sartre (dalam Nugroho, 2013) adalah "terjebak pada dunia orang lain". Dengan demikian, individu didefinisikan orang 
lain, ia tidak memiliki kuasa untuk menciptakan "narasinya" sendiri. Hampir setuap perilaku AZM terkerangka dalam perilaku pacarnya, dan inilah yang memunculkan ketakutan baik itu disadari ataupun tidak oleh AZM. Ketakutan yang dimaksud di sini adalah ketakutan AZM terhadap "kebebasannya sendiri". AZM bisa saja tidak mengambil pusing ancaman pacarnya, namun ini memiliki beberapa konsekuensi; Pertama, bisa jadi pacarnya hanya mengancam dirinya. Kedua, boleh jadi pacarnya memang akan bunuh diri jika AZM meninggalkannya. Inilah mengapa, Sartre berkata, "Kebebasan adalah pusaran kemungkinan di mana kita dibuat takut olehnya". Dalam kasus ini, AZM pada awalnya cenderung berusaha lari dari kebebasannya, meskipun pada akhirnya ia memenangkan kebebasannya dengan cara memutuskan pacarnya.

\section{Anatomi Konflik dan Resolusinya}

Lewis A. Coser mengatakan bahwa konflik dapat berdampak positif bagi interaksi. Hal serupa sebelumnya juga telah dikemukakan George Simmel, "Apabila interaksi dapat ditempatkan sebagai kerjasama, maka begitu pula seharusnya dengan konflik", ungkap Simmel (dalam Wolff, 1950). Hal ini dikarenakan, konflik sesungguhnya juga merupakan bentuk interaksi, hanya saja mengambil bentuk dan pola berlainan. Baik menurut Simmel maupun Coser, konflik dapat membantu masing-masing pihak lebih memahami kebutuhan satu sama lain, hal terkait pada gilirannya dapat memperkuat ikatan yang terjalin. Namun sebagaimana telah disinggung sebelumnya, apabila sejauh konflik tersebut tidak menyinggung "tema inti".
"Tema inti" yang dimaksudkan Coser (dalam Poloma, 1979) adalah suatu isu yang bersifat sangat pribadi (personal) yang membuat seseorang begitu sensitif akannya. Dalam hal ini, "tema inti" pun mengambil bentuk yang berbedabeda antarsatu pihak dengan pihak lainnya. Sebagai misal, terdapat pasangan yang merasa paling tidak nyaman (baca: tidak suka) apabila pasangannnya mengungkit mantan kekasih. Dengan demikian, isu itu menjadi tema intinya. Contoh lain, terdapat pasangan yang paling merasa tidak nyaman jika dibandingkan dengan sosok lain, maka hal ini menjadi tema intinya. Lebih jauh, apabila konflik yang terjadi menyinggung tema inti, maka konflik ini takkan memiliki dampak positif bagi setiap pihak, melainkan dapat mengakhiri hubungan keduanya.

Tema inti dari setiap pasangan pacaran ruparupanya berbeda-beda sebagaimana diungkapkan Coser. Terdapat pasangan yang menempatkan kurangnya perhatian sebagai tema inti, dan ada pula pasangan yang menempatkan keposesifan pasangan lain sebagai tema intinya. Tegas dan jelasnya, sejauh konflik yang terjadi dalam hubungan pacaran tersebut tidak menyinggung tema inti, maka konflik yang terjadi selalu dapat dicarikan resolusinya. Sementara, apabila telah menyinggung tema inti, maka konflik yang terjadi mengakhiri hubungan keduanya. Sebagai misal, terdapat remaja yang menempatkan agama sebagai tema inti, maka ia pun pada akhirnya harus merelakan kekasihnya yang berbeda agama bersama orang lain.

Lebih jauh, Coser (dalam Poloma, 1979) juga mengemukakan berbagai tipe konflik, antara lain; 
konflik realistis, konflik nonrealistis, serta konflik realistis tanpa antagonisme. Konflik realistis adalah konflik yang bersifat langsung dan konkret, dalam arti, subjek konflik mengemukakan kepentingan atau ketidakpuasannya secara langsung pada objek konflik utamanya. Konflik nonrealistis adalah konflik yang bersifat tidak langsung dan abstrak, yakni subjek konflik mengemukakan ketidakpuasannya pada objek perantara konflik, dan bukannya objek konflik utama. Sementara, konflik realistis tanpa antagonisme adalah konflik yang terjadi karena masing-masing pihak sekadar menempatkan diri pada status dan perannya.

Ketiga tipe konflik di awal ditemui dalam konflik hubungan pacaran. Konflik realistis terjadi apabila salah satu pasangan menjadi penyebab konflik secara langsung. Sebagai misal, ketika pasangan lebih memilih pergi bersama temantemannya, atau kurangnya perhatian, pun berbagai bentuk kekerasan yang dilakukan salah satu pasangan. Adapun konflik nonrealistis terjadi ketika terdapat pihak ketiga yang menyebabkan terjadinya ketegangan (konflik), namun pasangan justru melampiaskan langsung satu sama lain. Sebagai contoh, konflik yang disebabkan ketidaksetujuan orangtua terhadap hubungan, hal ini seringkali justru memicu konflik antarpasangan. Seyogiyanya, objek konflik langsung dari persoalan ini adalah orangtua pasangan, bukannya pasangan sendiri.

Di samping kedua tipe di awal, konflik realistis tanpa antagonisme dimisalkan dengan masingmasing pasangan yang berupaya menjalankan peran masing-masing sebagai pasangan yang "baik". Peran yang dijalankan ini lebih tampak sebagai permainan, sebagai misal, bagaimana salah satu pasangan menempatkan diri pada sosok orang lain, bertindak layaknya orang lain, dan lain sejenisnya. Meskipun bersifat sementara, namun hal ini dapat memicu konflik antarpasangan. Akan tetapi, konflik tipe ini selalu bisa diredam, dan tidak sampai mengakhiri hubungan pasangan.

Hal lain yang diungkapkan Coser (dalam Poloma, 1979) dalam teori konfliknya adalah keberadaan safety valve atau "katup penyelamat". Katup penyelamat yang dimaksud adalah pihak ketiga yang bisa menengahi konflik. Dengan kata lain, katup penyelamat berfungsi sebagai tempat di mana konflik dikelola. Katup penyelamat di sini dapat pula didaulat sebagai sarana untuk mendamaikan kedua belah pihak yang sedang bertikai, atau mencegah terjadinya skala konflik yang lebih besar.

Katup penyelamat antarpasangan ternyata berbeda-beda. Terdapat pasangan yang menempatkan sahabatnya sebagai penengah, saudaranya, bahkan orangtuanya. Namun uniknya, katup penyelamat seringkali justru tidak menjalankan fungsinya sebagai resolusi konflik. Pihak ketiga justru membuat skala konflik semakin luas dan tidak terukur. Dengan kata lain, katup penyelamat yang umumnya ditemukan justru tidak berperan mendamaikan konflik, melainkan membuat pasangan mengakhiri hubungannya.

\section{Simpulan}

Dalam hubungan pacaran setidaknya pelaku pernah menuai satu dari tiga bentuk kekerasan dalam interaksi sosial, yakni; simbolik, verbal, dan fisik. Terdapat pula kondisi kejiwaan yang cukup mengkhawatirkan diakibatkan oleh trauma hubungan pacaran yang dijalaninya. Namun demikian, terdapat pula yang memaklumi ber- 
bagai bentuk kekerasan yang diterimanya dari pasangan, hal ini dikarenakan ia menempatkannya sebagai "nasehat" bagi dirinya untuk memperbaiki diri-menjadi pribadi yang lebih baik. Lebih jauh, dapat disimpulkan bahwa: 1) Masih banyaknya pihak yang belum memahami berbagai bentuk kekerasan dalam interaksi sosial, terutama dalam hubungan pacaran, serta 2) Masih diperlukannya sosialisasi dan pemahaman pada khalayak luas ihwal berbagai bentuk kekerasan dalam interaksi sosial, yaitu kekerasan simbolik, verbal, dan fisik.]

\section{Daftar Pustaka}

Barker, Chris. 2009. Cultural Studies. Yogyakarta: Kreasi Wacana.

Bourdieu, Pierre. 2009. Arena Produksi Kultural. Yogyakarta: Kreasi Wacana.

Indrayani, Wiwit dan Ashaluddin Jalil. 2016. “Perilaku Berpacaran pada Remaja di Desa Batubelah Kecamatan Kampar, Kabupaten Kampar." JOM Fisip Universitas Riau 3(1):1-15.

Kilby, Jane dan Larry Ray. 2014. "Violence and Society: Toward a New Sociology Introduction." Sociological Review Journal 6(2).

Martin, Adrienne M. 2018. The Routledge Handbook of Love in Philosophy. London: Routledge.

Moleong, Lexy. J. 2011. Metodologi Penelitian Kualitatif. Bandung: Remaja Rosdakarya.

Muslimah, Siti. 2013. "Hubungan Antara Ekspresi Cinta dengan Perilaku Pacaran Remaja Madrasah Tsanawiyah." Tesis tidak dipublikasikan. Universitas Muhammadiyah Surakarta, Surakarta.
Nugroho, Wahyu Budi. 2013. Orang Lain Adalah Neraka: Sosiologi Eksistensialisme Jean Paul Sartre. Yogyakarta: Pustaka Pelajar.

Poloma, Margaret M. 1979. Contemporary Sociological Theory. MacMillan: University of Virginia:

Pratiwi, Nindyastuti Erika. 2012. "Gambaran Konsep Pacaran dan Perilaku Pacaran pada Remaja Awal." Skripsi tidak dipublikasikan. Universitas Indonesia, Jakarta.

Rahayu, Gusni. 2015. "Perspektif Pendidikan Islam tentang Pacaran: Menguak Pemikiran Ustadz Felix Y. Siauw." Skripsi tidak dipublikasikan. Universitas Islam Negeri Sunan Kalijaga, Yogyakarta.

Romaeti, Siti. 2011. "Dampak Pacaran terhadap Moralitas Remaja Menurut Ustadz Jefri AlBukhari." Skripsi tidak dipublikasikan. UIN Syarif Hidayatullah, Jakarta.

Sartre, Jean-Paul. 1956. Being and Nothingness. New York: Philosophical Library.

Selarani, Katrin. 2018. "Fenomena Pacaran Berbeda Agama di Kalangan Muda/i Kota Denpasar." Skripsi tidak dipublikasikan. Universitas Udayana, Denpasar.

Sharma, Daisy. 2015. "Role of Love in Relationship Satisfaction." The International Journal of Indian Psychology 3(1).

Usman, Sunyoto. 2004. Pengantar Sosiologi. Yogyakarta: CIRED.

Wieviorka, Michel. 2013. "Social Conflict." Current Sociology 61(5-6):696-713.

Wolff, Kurt H. 1950. The Sociology of Georg Simmel. Illnois: The Free Press.

Zeitlin, Irving M. 1973. Rethinking Sociology: A Critique of Contemporary Theory. New Jersey: Prentice-Hall. 
